\title{
Introduction of Medical Simulation and the Experience of Computerized Simulation Program Used by MicroSim ${ }^{\circledR}$
}

\author{
Sam-Beom Lee, Jae-Beum Bang*, Joon Sakong ${ }^{\dagger}$ \\ Department of Emergency Medicine, *Department of Medical Education and \\ ${ }^{\dagger}$ Department of Preventive Medicine and Public Health, \\ College of Medicine, Yeungnam University, Daegu, Korea
}

\begin{abstract}
-Abstract-
Background : Computer- and web-based simulation methods help students develop problem solving and decision making skills. In addition, they provide reality based learning to the student clinical experience with immediate medical feedback as well as repetitive training, on-site reviews and case closure.
\end{abstract}

Materials and Methods: Seventy-five third-year medical students participated in a two-week simulation program. The students selected four modules from eight modules as follows: airway and breathing 1, cardiac arrest 1, cardiac arrhythmia 1, and chest pain 1, and then selected the first case within each of the modules. After 2 weeks, a pass score was obtained and the data analyzed. The average pass score of over $70 \%$ was considered a passing grade for each module. If the student did not pass each module, there was no score (i.e., pass score was zero). In addition, when at least one of the four modules was zero, the student was not included in this study.

Results: Seventy-five students participated in the simulation program. Nineteen students were excluded based on their performance. The final number of students studied was 56 students (74.7\%). The average scores for each module 1 to 4 were $86.7 \%$, 85.3\%, 84.0\%, and $84.0 \%$, and the average obtained pass score was 88.6 for the four modules in all 56 students. Conclusion: Medical simulation enabled students to experience realistic patient situations as part of medical learning. However, it has not been incorporated into traditional educational methodology. Here we describe the introduction and the development of various simulation

책임저자 : 이삼범, 대구광역시 남구 대명5동 317-1, 영남대학교 의과대학 응급의학교실

Tel: (053) 620-3193, Fax: (053) 628-7106, E-mail: sblee@med.yu.ac.kr 
- Introduction of Medical Simulation and the Experience of Computerized Simulation Program Used by MicroSim ${ }^{\circledR}-$

modules and technologies for medical education.

Key Words: Medical simulation, MicroSim ${ }^{\circledR}$

\section{Introduction}

Medical simulation is a rapidly expanding area of within medical education. Simulationbased medical education (SBME) is complementary to traditional methods of medical education. ${ }^{1,2)}$ SBME includes verbal role play, animal models, human cadavers, standardized patients or simulated patients, simple skills trainers, procedural simulators, virtual reality, computer screen-based simulation, and fullscale integrated patient simulators. ${ }^{2-4)}$

Laerdal medical in Norway developed computer- and web-based simulation methods. The MicroSim ${ }^{\circledR}$ system has been widely used worldwide; it is a self-directed computer program that mainly simulates medical emergencies. It helps students develop problem solving and decision making skills, and also provides reality based learning of clinical situations with debriefing for immediate medical feedback and enables repetitive training, on-site review and case closure. ${ }^{4,5)}$

We present the results of a two week computer- and web-based simulation course as part of the Introduction to Clinical Medicine (ICM) for third-year medical students just before their clerkships and discuss simulationbased medical education and its various tools.

\section{Materials and Methods}

Seventy-five third-year medical students participated in a two week simulation program, at the Clinical Skills and Simulation Center (CSSC) and e-learning center at the lecture building of the Yeungnam University College of Medicine. MicroSim ${ }^{\circledR}$ inhospital version program (Laerdal medical in Norway, 2007) was already installed on the hospital network and was accessed by each computer (Fig. 1A). Each student had a seat equipped with a desktop computer with internet and

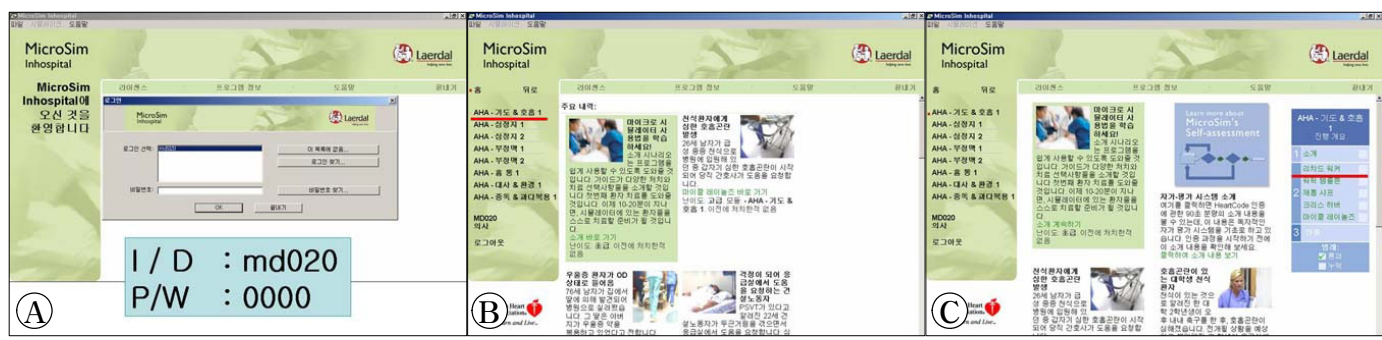

Fig. 1. Introduction of the MicroSim ${ }^{\circledR}$ program (Korean version). Picture $\mathrm{A}^{-} \mathrm{C}$ shows the methods of program access. 
headphones designated by student numbers and passwords.

The students were instructed to select four modules from eight available modules as follows: airway and breathing 1 (module 1), cardiac arrest 1 (module 2), cardiac arrhythmia 1 (module 3), and chest pain 1 (module 4), and then to select the first case from each of the modules (Fig. 1B, 1C).

For each of the selected cases, the students could enter that case file repeatedly during the two-week program. Repeated testing and personal review were performed until the final submission. After the two weeks, the instructor accessed the program on the server for the detailed report of the students.
A score was obtained and the pass and fail rate determined. An average pass score over $70 \%$ was considered as a passing score for each module. However, if the student did not pass each module, there was no score (i.e., pass score was zero). When one of four modules was zero, this student was excluded from this study.

\section{Results}

Seventy-five third-year medical students participated in a two-week simulation program. Nineteen students were excluded because of suspected program errors and student error; the final effective number was 56 students

Table 1. The final pass score for the four modules from the 56 students that passed all of the modules

\begin{tabular}{lcc}
\hline \multicolumn{1}{c}{ Modules } & $\begin{array}{c}\text { Average pass score } \\
(\mathrm{N}=56)\end{array}$ & $\begin{array}{c}\text { Passed rate } \\
(\mathrm{N}=75)\end{array}$ \\
\hline 1. Airway \& Breathing 1 & 92.6 & $86.7 \%$ \\
2. Cardiac arrest 1 & 86.8 & $85.3 \%$ \\
3. Cardiac arrhythmia 1 & 85.3 & $84.0 \%$ \\
4. Chest pain 1 & 89.6 & $84.0 \%$ \\
Average & 88.6 & $85.0 \%$ \\
\hline
\end{tabular}

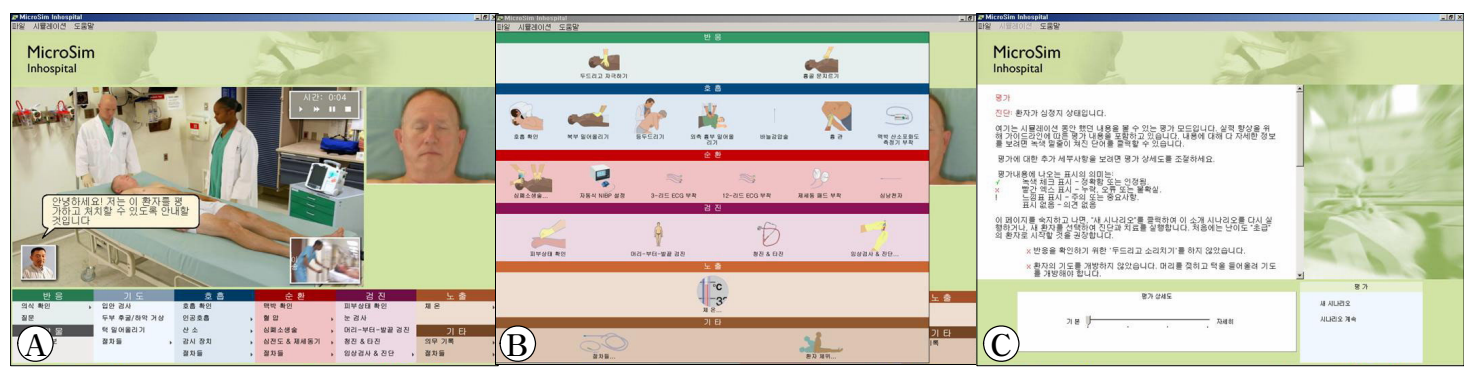

Fig. 2. The process of MicroSim ${ }^{\circledR}$ inhospital program (Korean version). A shows initial picture of simulation program after one case was selected, all menus are shown during whole process which will be selected, $\mathrm{B}$ shows detailed next procedures which will be selected during each process, and $\mathrm{C}$ shows personal reviews of results which performed by oneself. 
(74.7\%), included in this study. The pass rates for each module 1 to 4 were $86.7 \%$, $85.3 \%$, 84.0\%, and $84.0 \%$, were higher than the inclusion criteria, and the average pass score obtained was 88.6 for the four modules from the 56 students that passed all of the modules (Table 1).

\section{Discussion}

Simulation-based medical education (SBME) is complementary to traditional methods of medical education. SBME include verbal role play, animal models, human cadavers, standardized patients or simulated patients, simple skills trainers, procedural simulators, virtual reality, computer screen-based simulation, and full-scale integrated patient simulators. $^{2,3)}$

Advanced simulation technologies will fundamentally alter the landscape of medical education and practice across specialties. ${ }^{1)}$

The goal of medical simulation is to allow physicians and other healthcare professionals to develop and perfect their skills without risk to patients. This will improve patient safety by allowing healthcare professionals to practice procedures until they achieve proficiency, and it provides a training environment that does not put patients at risk. In addition, medical simulation can provide training to proficiency in rare, complicated, or otherwise error-prone tasks without practicing on patients. Therefore, it might be an effective was to reduce medical errors. Simulation-based medical training might reduce medical errors by offering repetitive practice and immediate performance feedback and a standardized approach to medical training. ${ }^{6}$

Procedural medicine lends itself well to the use of simulators, and this type of learning may improve patient safety. ${ }^{7)}$ Laerdal medical in Norway has developed computer- and web-based simulation methods; the MicroSim ${ }^{\circledR}$ program has been widely used worldwide. This system is a self-directed computer program that mainly simulates medical emergencies. It helps students develop problem solving and decision making skills, and also provides reality based learning with debriefing for immediate medical feedback as well as enabling enable repetitive training, on-site review and case closure., ${ }^{4)}$ Compared with formal didactic instruction, adult learners are particularly well suited to this form of experiential learning and debriefing. ${ }^{8}$ ) For further background on simulation, we refer readers to a review article by Issenberg, et $\mathrm{al}^{9)}$ as well as the books Simulators in Critical Care and Beyond, edited by Dunn, ${ }^{10}$ and Practical Health Care Simulations, edited by Loyd, et al. ${ }^{11}$

Microsim $^{\circledR}$ (Laerdal Medical) is an exciting new multimedia learning package that may be a useful adjunct to advanced life support (ALS) training. Microsim ${ }^{\circledR}$ is a new multimedia program that provides structured training 
and feedback on medical emergencies and ALS. The system contains a number of different modules covering the assessment of the critically ill patient, peri-arrest arrhythmias, cardiopulmonary resuscitation and post-resuscitation care (Fig. 2). ${ }^{12)}$ Eightytwo percent of students found the program useful. The students reported that the program improved their understanding in the following: the $\mathrm{ABCDE}$ approach (74\%), airway management (70\%), defibrillation (65\%), basic life support (70\%), ALS treatment algorithm (84\%), role of cardiac arrest team leader (70\%), and the role of team members (68\%). Seventy-six percent of students would recommend the program to their colleagues. Ten percent thought the program could replace the ALS course completely, while 15\% thought it could replace it partly. Fortyeight percent of the candidates preferred the program to the ALS manual. ${ }^{12)}$

The results of this study showed that among 75 third-year medical students that participated in a two-week simulation program, 19 were excluded and the final number of students that completed the program was 56 (74.7\%). However, the pass rates for each of the modules 1 to 4 were higher among the 56 students, and their average pass score obtained was $88.6 \%$ for the four modules (Table 1). Therefore, the Microsim ${ }^{\circledR}$ system was an exciting new multimedia learning package that might be considered as a useful adjunct to ALS training. ${ }^{12)}$
Medical simulation allows students to experience realistic patient situations without exposing patients to the risk inherent in medical students learning and is adaptable to situations involving widely varying clinical content. Although SBME is becoming more widely used in medical education, it is typically used as a complement to traditional educational methodology. ${ }^{13)}$

The SBME approach to medical learning might become an integral part of the medical curriculum and incorporated into continued medical education across all medical professions and throughout a physician's medical career. Here we describe the introduction and the development of various simulation modules and various simulation technologies, and their implementation, and report our initial experience with this technology at our medical college.

\section{요 약}

배경 : 의학시뮬레이션 교육방법이 새로이 도입 되면서 다양한 방법이 개발되었다. 특히 컴퓨 터와 인터넷을 이용한 시뮬레이션 교육이 학생 들에게 사전에 임상수기 교육 및 임상경험을 가능하게 하여 많은 도움을 주고 있다. 본 연 구는 Microsim ${ }^{\circledR}$ 프로그램을 이용한 학생들의 첫 경험을 보고하고 컴퓨터와 인터넷을 이용한 시뮬레이션 교육에 대하여 소개하고자 한다.

대상 및 방법 : 의학과 3학년 학생을 대상으로 임상의학입문 과정의 일환으로 $\mathrm{Microsim}^{\circledR}$ 프 로그램을 이용하여 2주간의 실습후 획득한 점 
- Introduction of Medical Simulation and the Experience of Computerized Simulation Program Used by MicroSim ${ }^{\circledR}-$

수를 산정하여 통과여부를 알아보고자 하였다. 모듈 1 은 기도 및 호흡, 모듈 2는 심정지, 모듈 3은 심장 부정맥, 모듈 4는 흉통으로 정하였으 며, 4 개의 모듈에서 미리 지정된 각각의 증례 하나를 선택하여 반복하여 실습하고 최종적으 로 각각 통과점수가 $70 \%$ 이상이 되어야 인정 되도록 하였다.

결과 : 전체 75 명의 학생이 참가하여 이중 56 명 (74.7\%)이 4 개의 모듈을 모두 통과하였다. 각 각의 모듈의 평균 통과율은 모듈 1이 $86.7 \%$, 모듈 2 가 $85.3 \%$, 모듈 3 과 4 가 각각 $84.0 \%$ 였 으며, 4 개 모듈의 평균점수는 88.6이었다.

결론 : 의학시뮬레이션이 비록 완전하게 통과되 지는 않았지만 학생들로 하여금 실제적인 임상 경험을 가능하게 하였다. 하지만 이는 아직은 기존의 교육방식의 보조적인 역할을 담당한다 고 할 수 있으며 향후 좀 더 다양한 방법으로 반복된 시뮬레이션 교육과 이에 대한 평가가 필요할 것으로 사료된다. 아울러 의학시뮬레이 션의 다양한 교육방법에 대하여 소개를 하고자 하였다.

\section{References}

1. Bond WF, Lammers RL, Spillane LL, SmithCoggins R, Fernandez R, Reznek MA, et al. The use of simulation in emergency medicine: a research agenda. Acad Emerg Med 2007 Apr;14(4):353-63.

2. Ziv A. Simulators and simulation-based medical education. In: Dent JA, Harden RM, editors. A practical guide for medical teachers. 2nd ed. Elsevier; 2005. p.211-20.

3. Jones JS, Hunt SJ, Carlson SA, Seamon JP. Assessing bedside cardiologic examination skills using "Harvey," a cardiology patient simulator. Acad Emerg Med 1997 Oct;4(10): 980-5.

4. Roy MJ, Sticha DL, Kraus PL, Olsen DE. Simulation and virtual reality in medical education and therapy: a protocol. Cyberpsychol Behav 2006 Apr;9(2):245-7.

5. Cavanaugh S. Computerized simulation technology for clinical teaching and testing. Acad Emerg Med 1997 Oct;4(10):939-43.

6. http://www.simquest.com

7. Patel AA, Glaiberman C, Gould DA. Procedural simulation. Anesthesiol Clin 2007 Jun;25(2): 349-59.

8. Custers E, Boshuizen H. The psychology of learning. In: Norman GR, van der Vleuten CPM, Newble DI (eds). International handbook of research in medical education. Dordrecht, Netherlands: Kluwer Academic; 2002. p.163203.

9. Issenberg SB, McGaghie WC, Petrusa ER, Lee Gordon D, Scalese RJ. Features and uses of high-fidelity medical simulations that lead to effective learning: a BEME systematic review. Med Teach 2005 Jan;27(1):10 - 28.

10. Dunn WF. Simulators in critical care and beyond. Des Plaines, IL: Soc Critical Med; 2004.

11. Loyd GE, Lake CL, Greenbert R. Practical health care simulations. Philadelphia: PA: Elsevier Mosby; 2004.

12. Perkins GD. Green C, Farquharson W, Lockey AS. MicroSim - A new tool for advanced life support training. Resuscitation 2006 Apr;69:54.

13. Binstadt ES, Walls RM, White BA, Nadel ES, Takayesu JK, Barker TD, et al. A comprehensive medical simulation education curriculum for emergency medicine residents. Ann Emerg Med 2007 Apr;49(4):495-504. 